\title{
Isolation and Structure Elucidation of Thiazomycin
}

\section{-A Potent Thiazolyl Peptide Antibiotic from Amycolatopsis fastidiosa}

\author{
Hiranthi Jayasuriya, Kithsiri Herath, John G. Ondeyka, Chaowei Zhang, \\ Deborah L. Zink, Mark Brower, Francis P. Gailliot, Joyce Greene, Gwyneth Birdsall, \\ Jayashree Venugopal, Misti Ushio, Bruce Burgess, Greg Russotti, Andre Walker, \\ Michelle Hesse, Anna Seeley, Beth Junker, Neal Connors, Oscar Salazar, \\ Olga Genilloud, Kun Liu, Prakash Masurekar, John F. Barrett, Sheo B. Singh
}

Received: June 2, 2007 / Accepted: August 17, 2007

(C) Japan Antibiotics Research Association

\begin{abstract}
Thiazolyl peptides are a class of rigid macrocyclic compounds richly populated with thiazole rings. They are highly potent antibiotics but none have been advanced to clinic due to poor aqueous solubility. Recent progress in this field prompted a reinvestigation leading to the isolation of a new thiazolyl peptide, thiazomycin, a congener of nocathiacins. Thiazomycin possesses an oxazolidine ring as part of the amino-sugar moiety in contrast to the dimethyl amino group present in nocathiacin I. The presence of the oxazolidine ring provides additional opportunities for chemical modifications that are not possible with other nocathiacins. Thiazomycin is extremely potent against Gram-positive bacteria both in vitro and in vivo. The titer of thiazomycin in the fermentation broth was very low compared to the nocathiacins I and III. The lower titer together with its sandwiched order of elution presented significant challenges in large scale purification of thiazomycin. This problem was resolved by the development of an innovative preferential protonation
\end{abstract}

S. B. Singh (Corresponding author), H. Jayasuriya, K. Herath, J. G. Ondeyka, C. Zhang, D. L. Zink, M. Brower, F. P. Gailliot, J. Greene, G. Birdsall, J. Venugopal, M. Ushio, B. Burgess, G. Russotti, A. Walker, M. Hesse, A. Seeley, B. Junker, N. Connors, K. Liu, P. Masurekar, J. F. Barrett: Merck Research Laboratories, Rahway, New Jersey, USA,

E-mail: sheo_singh@merck.com

O. Salazar, O. Genilloud: Centro de Investigación Básica, Merck Sharp \& Dohme de España, S. A. Josefa Valcárcel 38, Madrid 28027, Spain

J. F. Barrett: Deceased based one- and/or two-step chromatographic method, which was used for pilot plant scale purifications of thiazomycin. The isolation and structure elucidation of thiazomycin is herein described.

Keywords antibiotics, thiazolyl peptide, protein synthesis inhibitors, natural products

\section{Introduction}

The discovery of penicillin and other antibacterial agents of microbial origin to treat infections from pathogenic bacteria is arguably one of the greatest achievements of the science and medicine of mid twentieth century $[1,2]$. Incremental improvements to those discoveries led to development of new and improved antibiotics, which continue to serve humanity well. However, bacteria are adapting to these antibiotics rendering them ineffective, and leading to the emergence of resistance. Fortunately the frequency of resistance is quite variable amongst different bacterial species and the strains that are resistant to one antibiotic are susceptible to many other. A most frightening situation would be when bacterial strains become resistant to multiple antibiotics leading to the limited or no treatment options. Although these situations have started to emerge (e.g., refractory methicillin resistant Staphylococcus aureus and others), fortunately they remain rare. In order to treat such infections and avoid an epidemic to occur, new treatment options must be made available by discovery of new structural chemotypes that inhibit growth of bacteria 
by new modes of action (e.g., platensimycin [3,4] and platencin $[5,6])$.

Thiazolyl peptides are a class of naturally occurring antibiotics produced by prokaryotic organisms. The discovery of these compounds dates back to late forties (e.g., micrococcin in 1948) and early fifties (e.g., thiostrepton in 1954) [7]. These compounds have been shown to exhibit some of the most potent in vitro activities, but they have not been developed as clinical agents due to poor physicochemical properties, most notably low aqueous solubility. However, key attributes of this class of natural products, such as highly potent activity and new modes of action, prompted us to study them further. Our research laboratories studied thiostrepton in the early eighties without making much progress in terms of development $[8,9]$. Significant advances in biology and chemistry have taken place since then. Upon closer examination of this chemical class, compounds such as glycothiohexide $\alpha$ $[10,11]$, S54832A-I [7], MJ347-81F4A and B [12] and nocathiacins $[13,14]$ appeared more attractive than the rest because they contained aminoglycosidic residue, which inherently provided potential for improvement of aqueous solubility. This was illustrated by chemical modifications of nocathiacin I [13 23]. Therefore, we initiated an investigation to discover new thiazolyl peptides with chemical functionalities that can provide additional opportunities for chemical modifications, which could lead to compounds with better physical and pharmaceutical properties. Such compounds could be amenable to development as new antibiotics without cross resistance to existing antibiotics. To accomplish our goal, we acquired known producers of thiazolyl peptides and related cultures from internal and external sources and subjected them to both biological and chemical screening.

LCMS screening of the extracts of Nocardia sp. ATCC 202099 (renamed Amycolatopsis fastidiosa) indicated the presence of new thiazolyl peptides. Chromatographic fractionation of an extract led to the isolation of four known compounds nocathiacins I $\sim$ IV $(\mathbf{1} \sim \mathbf{4})$ and a new thiazolyl peptide, thiazomycin (5). The isolation, structure elucidation, and large scale production of thiazomycin are herein described. Full biological characterization of thiazomycin is reported in the accompanying paper [24].

\section{Results and Discussion}

\section{Revised Classification of the Producing Strain}

The strain MA7332 (ATCC 202099) grows well at $28^{\circ} \mathrm{C}$ in a good range of agar media such as Yeast Malt Extract, Oatmeal, Glycerol Asparagine, Inorganic Salts Starch and Trypticase Soy agars, in the form of wrinkled yellowish small colonies. Microscopically the strain forms a sterile and extensively branched substrate mycelium that, even after long incubations, shows no traces of hyphal fragmentation or maturation of rudimentary aerial hyphae, morphological traits not corresponding to members of Nocardia spp. The taxonomic position of the producing

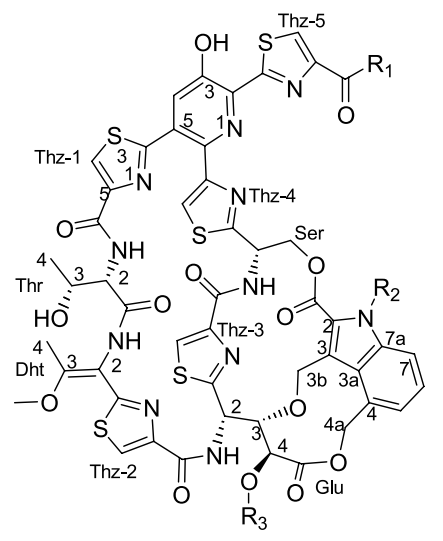

1 (Nocathiacin I)

2 (Nocathiacin II)<smiles>C=C(N)C(N)=O</smiles>

$\mathrm{H}$<smiles>C=C(N)C(N)=O</smiles>

$\mathrm{H}$

4 (Nocathiacin IV)

5 (Thiazomycin)
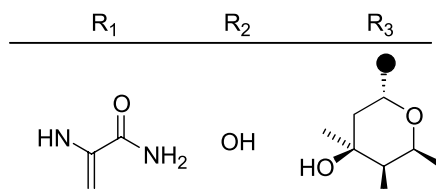<smiles>CC1OCC[C@](C)(O)C1N(C)C</smiles>

3 (Nocathiacin III)

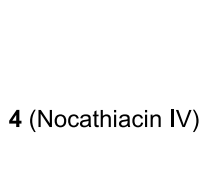

$\mathrm{OH}$<smiles>CC1O[C@H](C)C[C@](C)(O)C1N(C)C</smiles>
$\mathrm{OH}$

$\mathrm{H}$<smiles>C=C(N)C(N)=O</smiles>

$\mathrm{OH}$ 
organism, originally identified as a Nocardia sp., was re-evaluated on the basis of new molecular data obtained in the course of this study. A phylogenetic study based on 16S rDNA sequences (GenBank accession EU072442) from representative members of the families Nocardiaceae, Pseudonocardiaceae and Actinosynnemataceae shows the relatedness of the strain with the type species $A$. fastidiosa ATCC31181, a relationship highly supported by

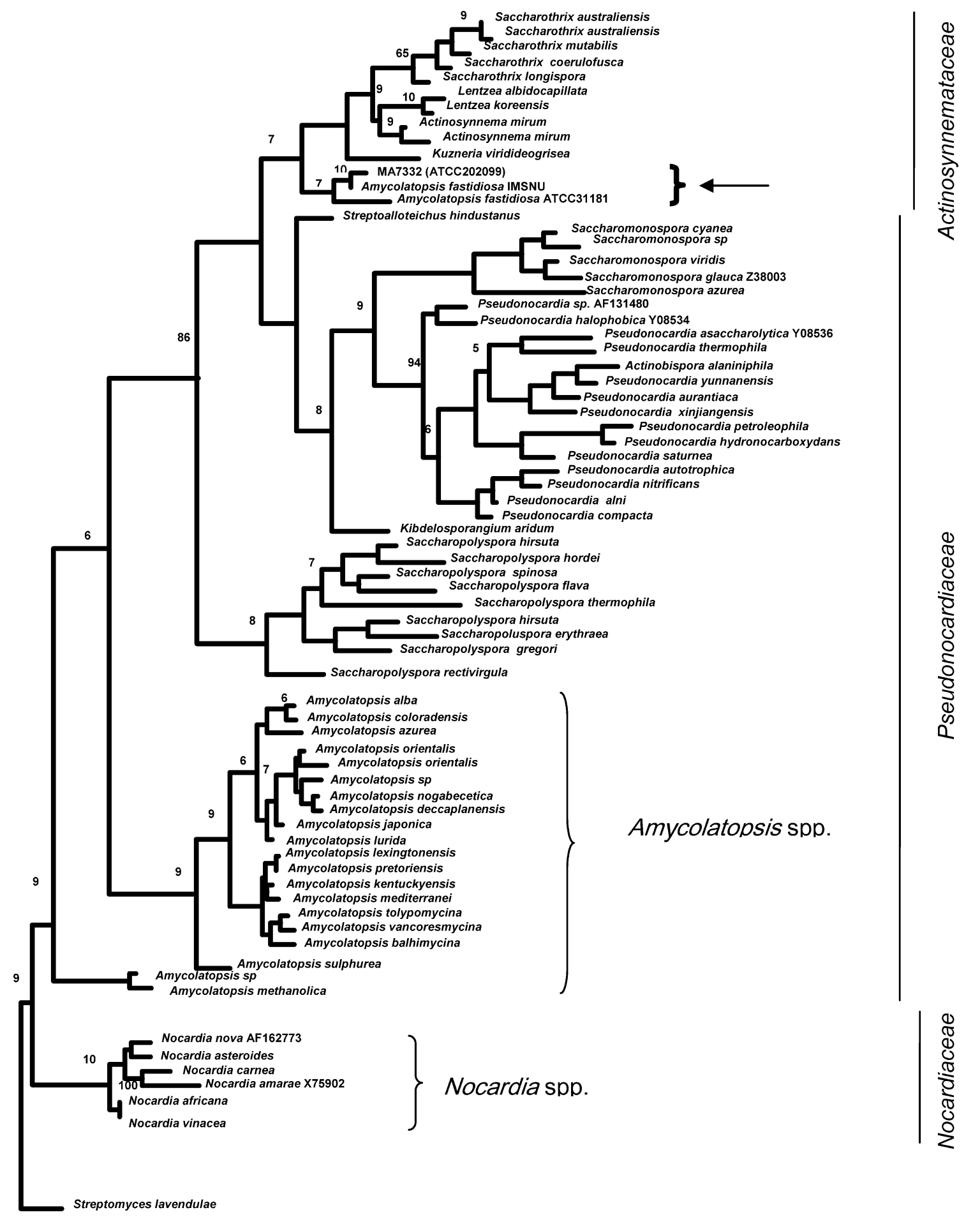

Fig. 1 Neighbor joining phylogenetic tree based on almost complete 16S rDNA sequences of the strain MA7332 and species of the families Nocardiaceae, Actinosynnemataceae and Pseudonocardiaceae.

The numbers above branches indicate bootstrap support (\%) based on analysis of 1000 replicates. Only values above $50 \%$ are shown. 
bootstrap values (Fig. 1). This new molecular data supports a re-evaluation of the taxonomic position of the strain MA7332 that should not longer be associated to strains of the genus Nocardia, and therefore we propose for its reclassification as a new member of the species $A$. fastidiosa. Nevertheless taking into account the external position of the type species A. fastidiosa with regard to the other members of the family Pseudonocardiaceae, and its closest relationship to members of the family Actinosynnemataceae, additional studies are needed to resolve the taxonomic position of this clade within the family Pseudonocardiaceae.

\section{Initial Isolation of Thiazomycin}

Initial isolation of thiazomycin was accomplished by ethyl acetate and acetone extractions of the fermentation broth followed by successive chromatographic steps on silica gel, Sephadex LH20, and RP HPLC. This process allowed the purification of $17.5 \mathrm{mg}$ of thiazomycin from 18 liters of fermentation broth.

5 was present as a minor metabolite $(1 \sim 2 \mathrm{mg} /$ liter $)$ in the fermentation broth that contained a 10 100 fold excess of 1 (100 200 mg/liter) and $3(50 \sim 100 \mathrm{mg})$, along with minor amounts of $2(2 \sim 5 \mathrm{mg} /$ liter $)$ and 4 (1 5 mg/liter). This presented significant challenges to its purification in larger quantities. The purification was complicated, not only due to its low concentration, but also due to its order of chromatographic elution with respect to other major thiazolyl peptides produced. In the elution profile, thiazomycin was sandwiched between the two major metabolites, $\mathbf{1}$ and $\mathbf{3}$. Both $\mathbf{1}$ and $\mathbf{5}$ contain a basic tertiary nitrogen in the amino sugar residue, which was fortunately absent in $\mathbf{3}$. 1 possesses a dimethyl amino group whereas $\mathbf{5}$ possesses an oxazolidine ring. The differences in the $\mathrm{pKa}$ of the basic nitrogens of these compounds were sufficient for differential protonation to occur in the presence of certain acids, which in turn led to significant alternations in their chromatographic properties.

Of all the acids tested, TFA selectively protonated $\mathbf{1}$ in the presence of $\mathbf{3}, \mathbf{5}$, and other related compounds most efficiently (Fig. 2) thus allowing for differential protonation to occur and development of the purification method. The success of the differential protonation method depended on the complete protonation of $\mathbf{1}$. Partial protonation of $\mathbf{1}$ complicated the purification process due to co-elution of un-protonated $\mathbf{1}$ with $\mathbf{5}$, which necessitated the careful monitoring of the extent of protonation of $\mathbf{1}$. To accomplish this, a two dimensional TLC system was used. In this system, fully protonated 1 remained at the baseline of the TLC plate (Fig. 2, top panel, plates A and B); whereas partially protonated or un-protonated $\mathbf{1}$ moved with $\mathbf{5}$

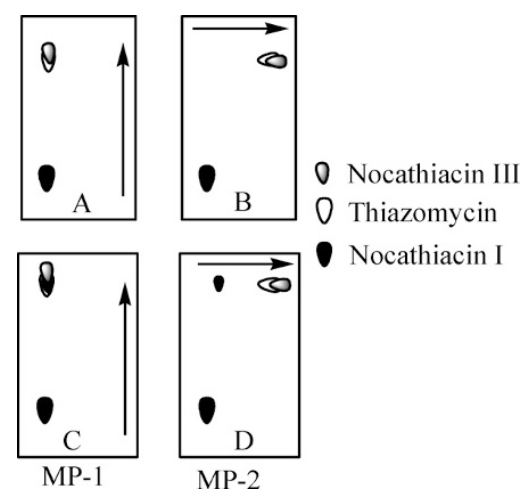

Fig. $22 D$ TLC method to detect the differential protonation of nocathiacin I.

Top panel: TLC plates A and B containing feed with complete protonation of nocathiacin I, bottom panel: TLC plates C and D containing feed with incomplete protonation of nocathiacin I, Mobile phases: (MP-1) $10 \% \mathrm{MeOH}$ in $\mathrm{CH}_{2} \mathrm{Cl}_{2}$, (MP-2) $10 \% \mathrm{MeOH}$ in $\mathrm{CH}_{2} \mathrm{Cl}_{2}+1 \% \mathrm{AcOH}$.

without any resolution after the first development (plate C). One percent acetic acid used in the development solvent in the second dimension protonated the un-protonated $\mathbf{1}$, thereby resolving it from the thiazomycin (plate D). Therefore if the protonation of $\mathbf{1}$ in the sample was complete, there would be no $\mathbf{1}$ present at the baseline after the development in the second dimension. The TLC spots were visualized under UV light. Interestingly, TFA in the mobile phase caused retardation of the mobility of $\mathbf{5}$ from $\mathbf{3}$ and 1. This observation allowed us to develop a one-step purification of $\mathbf{5}$ using silica gel chromatography in which the crude extract was acidified with TFA and pre-adsorbed on to silica gel before charging on the silica gel column.

(a) One-step Purification

In a typical experiment, a methyl ethyl ketone extract of the broth was concentrated to an aqueous layer leading to precipitation of thiazolyl peptides which were collected and washed with hexane or heptane. The precipitate was dissolved in methylene chloride-methanol containing $1.0 \%$ TFA, adsorbed on to a minimum amount of silica gel, and chromatographed on to a dry-packed column preequilibrated with methylene chloride. The optimal ratio of the feed to silica gel was about $1: 25$ (wt/wt). The column was then eluted with various proportions of methanol in methylene chloride, followed by $1.0 \% \mathrm{NH}_{4} \mathrm{OH}$ to separate 3, 5 and $\mathbf{1}$ (Fig. 3).

(b) Two-step Purification-pilot Plant Scale

Although the aforementioned method was acceptable for the purification of $\mathbf{5}$ at the laboratory scale, the use of chlorinated solvent and the pre-adsorption on silica gel before loading made it unsuitable for use in the pilot 
Silica chromatography (1:25)

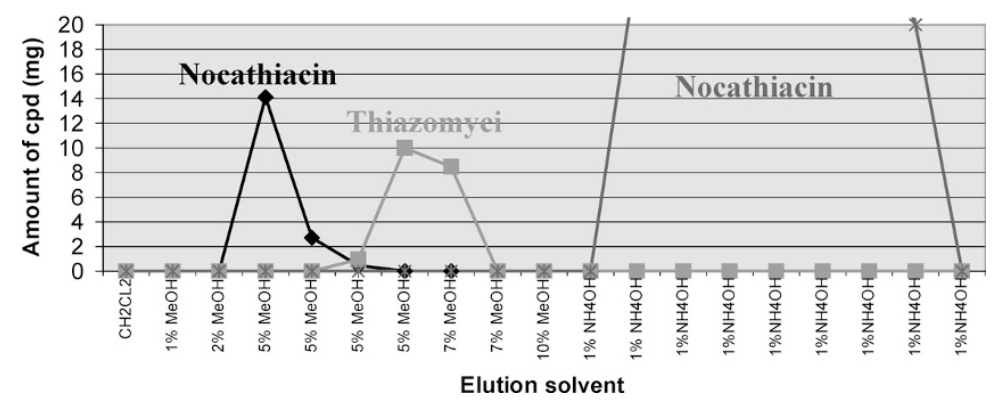

Fig. 3 Elution profile of thiazomycin and nocathiacins from the silica gel column.

plant or in the factory. After extensive studies, THF was identified as a replacement solvent for methylene chloride which necessitated insertion of a second step and a twostep chromatographic method was developed for the purification. The precipitate from the concentration of the MEK extract was dissolved in THF, concentrated to dryness and re-dissolved in a mixture of TFA-THF and charged directly to a silica gel column (capture step), which was equilibrated with TFA acidified THF. After loading, the column was washed with THF, and thiazomycin was eluted with $1.0 \% \mathrm{NH}_{4} \mathrm{OH}$ in THF. The rich cut was similarly rechromatographed on a small polishing column. This led to highly pure $\mathbf{5}$ with THF stabilizer, which was removed by washing with acetone to yield $>95 \%$ pure 5 .

\section{Structure Elucidation}

HRESIFT-MS analysis of $\mathbf{5}$ indicated a molecular ion at $m / z 1435.2707(\mathrm{M}+\mathrm{H})$ and provided a molecular formula $\mathrm{C}_{61} \mathrm{H}_{58} \mathrm{~N}_{14} \mathrm{O}_{18} \mathrm{~S}_{5}$ which was two hydrogen atoms less than the formula of $\mathbf{1}$. The mass spectrum produced a fragment ion at $m / z 1266$, an ion also produced by $\mathbf{1}$, suggesting an identical core structure for both compounds (Fig. 4). These data indicated that the structural differences resided in the amino sugar residue. The complete set of ${ }^{1} \mathrm{H}-,{ }^{13} \mathrm{C}-$, COSY, HMQC and HMBC data was recorded in DMSO and in a mixed solvent consisting of $\mathrm{CDCl}_{3} / \mathrm{CD}_{3} \mathrm{OD} 5: 1$. The mixed solvent system produced much better resolution and sharpness of the ${ }^{1} \mathrm{H}-\mathrm{NMR}$ signals and yielded a better data set which was used in the structure elucidation (Table 1). Both the ${ }^{1} \mathrm{H}$ - and the ${ }^{13} \mathrm{C}-\mathrm{NMR}$ spectra of $\mathbf{5}$ supported the presence of the tricyclic thiazolyl peptide motif core of $\mathbf{1}$. Comparison to the ${ }^{1} \mathrm{H}-\mathrm{NMR}$ spectral data of $\mathbf{5}$ with that of 1 suggested the presence of only one amino-methyl group $\left(\delta_{\mathrm{H}} 2.7, \mathrm{~s}\right)$ in $\mathbf{5}$ and showed the presence of a pair of self coupled doublets ( $\delta_{\mathrm{H}} 4.25$ and 5.13 ) with $J$ values of $5.5 \mathrm{~Hz}$ correlating to a methylene $\delta_{\mathrm{C}} 83.4 \mathrm{ppm}$ in the HMQC spectrum. The new methylene group displayed HMBC

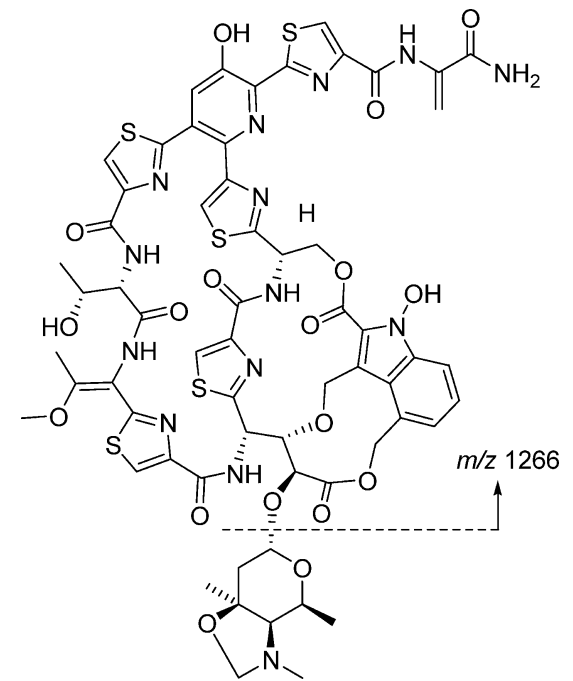

Fig. 4 Key ESI-MS fragmentation of thiazomycin.

correlations to the NMe-4 $\left(\delta_{\mathrm{C}} 40.0\right)$ and C-3 $(\delta$ 81.7) (Table 1) indicating the presence of the oxazolidine ring. The ${ }^{1} \mathrm{H}$ - and ${ }^{13} \mathrm{C}$-NMR spectra were assigned by a comparison with corresponding spectra of $\mathbf{1}$ and verified by HMQC and HMBC experiments. The NMR spectra of $\mathbf{5}$ in the mixed solvents were highly dependent on the concentration of solute and the ratio of the two solvents. In the mixed solvents, many $\mathrm{NH}$ protons were slow to exchange and could be easily detected but most exchanged over time and were not useful for HMBC. Reduction of $\mathbf{5}$ with sodium cyanoborohydride in acidic conditions produced 1 in high yield which was compared directly (coHPLC, ${ }^{1} \mathrm{H}-\mathrm{NMR}$, HRLCFT-MS) with an authentic sample of $\mathbf{1}$ isolated from the fermentation broth. Thus the relative and absolute configuration of $\mathbf{5}$ is confirmed to be identical to 1 .

The aqueous solubility of $\mathbf{5}(<0.1 \mathrm{mg} / \mathrm{ml})$ was slightly poorer than $1(<0.2 \mathrm{mg} / \mathrm{ml})$ in water. These compounds 
Table $1{ }^{1} \mathrm{H}$ - and ${ }^{13} \mathrm{C}-\mathrm{NMR}$ assignments of thiazomycin (5) in $\mathrm{CDCl}_{3}-\mathrm{CD}_{3} \mathrm{OD}(5: 1)$

\begin{tabular}{|c|c|c|c|}
\hline Position & $\delta_{\mathrm{C}}$ & $\delta_{\mathrm{H}}, J, \mathrm{~Hz}$ & $\mathrm{HMBC} \mathrm{C} \rightarrow \mathrm{H}$ \\
\hline \multicolumn{4}{|l|}{ Thz-1 (N) } \\
\hline Thz-1 $\left(\mathrm{C}_{2}\right)$ & 164.9 & - & Thz1-H-4, Pyr-H-4 \\
\hline Thz-1 $\left(C_{4}\right)$ & 125.4 & $8.35, \mathrm{~s}$ & \\
\hline Thz-1 $\left(C_{5}\right)$ & 148.8 & - & Thz1-H-4 \\
\hline Thz-1 (CO) & 159.5 & - & Thz1-H-4 \\
\hline Thr (CO) & 167.4 & & \\
\hline Thr (NH) & & $7.84, d, 6.0$ & \\
\hline $\operatorname{Thr}\left(\mathrm{C}_{2}\right)$ & 56.1 & $4.15, \mathrm{~m}$ & Thr- $\mathrm{H}_{3}-4$ \\
\hline $\operatorname{Thr}\left(\mathrm{C}_{3}\right)$ & 64.3 & $2.87, \mathrm{~m}$ & Thr- $\mathrm{H}_{3}-4$ \\
\hline $\operatorname{Thr}\left(\mathrm{C}_{4}\right)$ & 17.8 & $1.13, d, 6.0$ & \\
\hline \multicolumn{4}{|l|}{ Dht (NH) } \\
\hline Dht $\left(\mathrm{C}_{2}\right)$ & 110.0 & & Dht- $\mathrm{H}_{3}-4$ \\
\hline Dht $\left(\mathrm{C}_{3}\right)$ & 159.3 & & Dht- $\mathrm{H}_{3}-4, \mathrm{OMe}$ \\
\hline Dht $\left(\mathrm{C}_{4}\right)$ & 13.4 & $1.84, \mathrm{~s}$ & \\
\hline Dht (OMe) & 55.6 & $3.77, \mathrm{~s}$ & \\
\hline \multicolumn{4}{|l|}{ Thz-2 (N) } \\
\hline Thz-2 $\left(\mathrm{C}_{2}\right)$ & 162.1 & - & Thz2-H-4 \\
\hline Thz-2 $\left(\mathrm{C}_{4}\right)$ & 124.0 & $7.89, \mathrm{~s}$ & \\
\hline Thz-2 ( $\left.\mathrm{C}_{5}\right)$ & 145.5 & & Thz2-H-4 \\
\hline Thz-2 (CO) & 160.3 & & Thz2-H-4, Glu-H-2 \\
\hline Glu (NH) & & $8.36, d, 10.0$ & \\
\hline Glu $\left(\mathrm{C}_{2}\right)$ & 48.5 & $5.91, \mathrm{dd}, 10.0,1.0$ & Glu-H-4 \\
\hline Glu $\left(\mathrm{C}_{3}\right)$ & 81.1 & $3.87, \mathrm{dd}, 10.0,1.0$ & Glu-H-2, Glu-H-4, Indole-H-3b \\
\hline Glu $\left(C_{4}\right)$ & 69.6 & $4.36, d, 10.0$ & \\
\hline Glu (CO) & 171.4 & & Glu-H-4, Indole- $\mathrm{H}-4^{\mathrm{a}}$ \\
\hline \multicolumn{4}{|l|}{ Thz-3 (N) } \\
\hline Thz-3 $\left(C_{2}\right)$ & 166.1 & & Thz3-H-4 \\
\hline Thz-3 $\left(C_{4}\right)$ & 124.9 & $8.19, \mathrm{~s}$ & \\
\hline Thz-3 $\left(C_{5}\right)$ & 149.5 & & Thz3-H-4 \\
\hline Thz-3 (CO) & 161.4 & & Thz3-H-4 \\
\hline Ser (NH) & & $8.05, d, 10$ & \\
\hline $\operatorname{Ser}\left(C_{2}\right)$ & 48.8 & $5.63, \mathrm{dd}, 11.0,6.5$ & Ser-H-3 \\
\hline \multirow[t]{2}{*}{$\operatorname{Ser}\left(C_{3}\right)$} & 64.3 & 4.37, brd, 11.0 & \\
\hline & & $5.22, \mathrm{dd}, 11.0,6.0$ & \\
\hline \multicolumn{4}{|l|}{ Thz-4 (N) } \\
\hline Thz-4 $\left(\mathrm{C}_{2}\right)$ & 168.8 & & Thz4-H-4, Ser-H-3, Ser-H-2 \\
\hline Thz-4 $\left(\mathrm{C}_{4}\right)$ & 120.1 & 7.67, s & \\
\hline Thz-4 $\left(C_{5}\right)$ & 154.9 & & Thz4-H-4 \\
\hline $\operatorname{Pyr}\left(\mathrm{C}_{2}\right)$ & 134.2 & & Pyr-H-4 \\
\hline $\operatorname{Pyr}\left(\mathrm{C}_{3}\right)$ & 151.1 & & Pyr-H-4 \\
\hline $\operatorname{Pyr}\left(\mathrm{C}_{4}\right)$ & 126.5 & 7.57, s & \\
\hline $\operatorname{Pyr}\left(\mathrm{C}_{5}\right)$ & 129.8 & & Pyr-H-4 \\
\hline $\operatorname{Pyr}\left(\mathrm{C}_{6}\right)$ & 143.7 & & Pyr-H-4 \\
\hline \multicolumn{4}{|l|}{ Thz-5 (N) } \\
\hline Thz-5 $\left(\mathrm{C}_{2}\right)$ & 169.1 & & Thz5-H-4, Pyr-H-4 (w) \\
\hline Thz-5 $\left(\mathrm{C}_{4}\right)$ & 125.5 & $8.18, \mathrm{~s}$ & \\
\hline Thz-5 $\left(C_{5}\right)$ & 149.4 & & Thz5-H-4 \\
\hline Thz-5 (CO) & 158.4 & & \\
\hline \multicolumn{4}{|l|}{ Deala (NH) } \\
\hline Deala $\left(\mathrm{C}_{2}\right)$ & 132.7 & & Deala-H-3 \\
\hline
\end{tabular}


Table 1 Continued

\begin{tabular}{|c|c|c|c|}
\hline Position & $\delta_{\mathrm{C}}$ & $\delta_{\mathrm{H}}, J, \mathrm{~Hz}$ & $\mathrm{HMBC} \mathrm{C} \rightarrow \mathrm{H}$ \\
\hline Deala $\left(\mathrm{C}_{3}\right)$ & 104.3 & $\begin{array}{l}5.59, \mathrm{~s} \\
6.53, \mathrm{~s}\end{array}$ & \\
\hline $\begin{array}{l}\text { Deala }(\mathrm{CO}) \\
\text { Deala }\left(\mathrm{NH}_{2}\right)\end{array}$ & 165.9 & & Deala-H-3 \\
\hline $\begin{array}{l}\text { Indole (CO) } \\
\text { Indole }(\mathrm{OH})\end{array}$ & 161.1 & & Ser-H-3 \\
\hline Indole $\left(\mathrm{C}_{2}\right)$ & 126.6 & & Indole-H-3b \\
\hline Indole $\left(\mathrm{C}_{3}\right)$ & 109.7 & & Indole-H-3b \\
\hline Indole $\left(\mathrm{C}_{3 a}\right)$ & 119.1 & & Indole-H-3b; H-4a, H-5 \\
\hline Indole $\left(\mathrm{C}_{3 \mathrm{~b}}\right)$ & 65.8 & $\begin{array}{l}4.12, d, 10.0 \\
4.78, d, 10.0\end{array}$ & \\
\hline Indole $\left(\mathrm{C}_{4}\right)$ & 127.5 & & Indole-H-3b, H-4a, H-6 \\
\hline Indole $\left(\mathrm{C}_{4 \mathrm{a}}\right)$ & 67.9 & $\begin{array}{l}4.90, d, 12.5 \\
5.95, d, 12.5\end{array}$ & Indole-H-5 \\
\hline Indole $\left(C_{5}\right)$ & 123.6 & $7.08, d, 7.0$ & Indole-H-4 ${ }^{\mathrm{a}}$ \\
\hline Indole $\left(\mathrm{C}_{6}\right)$ & 124.9 & $7.32, t, 7.0$ & \\
\hline Indole $\left(C_{7}\right)$ & 112.1 & $7.69, d, 7.0$ & Indole-H-5 \\
\hline Indole $\left(\mathrm{C}_{7 \mathrm{a}}\right)$ & 135.1 & & Indole-H-6 \\
\hline Sug $\left(C_{1}\right)$ & 93.2 & $5.04, d d, 7.5,5.5$ & Glu-H-4, Sug-H-5, H-2 \\
\hline Sug $\left(C_{2}\right)$ & 35.1 & $\begin{array}{l}1.90, \mathrm{dd}, 15.0,7.5 \\
2.40, \mathrm{dd}, 15.0,5.5\end{array}$ & Sug-C3- $\mathrm{CH}_{3}$ \\
\hline Sug $\left(\mathrm{C}_{3}\right)$ & 81.7 & & Sug- $\mathrm{CH}_{3}-3$. Sug- $\mathrm{H}-2, \mathrm{H}-4, \mathrm{O}-\mathrm{CH}_{2}-\mathrm{N}$ \\
\hline Sug $\left(\mathrm{C}_{3}-\mathrm{Me}\right)$ & 24.2 & $1.43, \mathrm{~s}$ & Sug- $\mathrm{H}-2, \mathrm{H}-4$ \\
\hline Sug $\left(C_{4}\right)$ & 71.7 & 3.05, brs & Sug- $\mathrm{CH}_{3}-3$, Sug-H-2, N-Me \\
\hline Sug $\left(\mathrm{C}_{4}-\mathrm{NMe}\right)$ & 40.0 & $2.70, \mathrm{~s}$ & Sug- $\mathrm{H}-4, \mathrm{O}-\mathrm{CH}_{2}-\mathrm{N}$ \\
\hline Sug $\left(C_{5}\right)$ & 62.7 & $3.91, \mathrm{~m}$ & \\
\hline Sug $\left(C_{6}\right)$ & 15.7 & $0.74, d, 7.0$ & \\
\hline $\mathrm{O}-\mathrm{CH}_{2}-\mathrm{N}$ & 83.4 & $\begin{array}{l}4.25, \text { brd, } 5.5 \\
5.13, \text { brd, } 5.5\end{array}$ & $\mathrm{~N}-\mathrm{Me}$ \\
\hline
\end{tabular}

turned out to be unstable in phosphate buffer at $\mathrm{pH}$ ranges $3 \sim 7$. The presence of an oxazolidine ring in the aminosugar portion of $\mathbf{5}$ provides additional opportunities for chemical modifications that could lead to derivatives with increased water solubility and improved pharmaceutical properties. Although this compound was produced as a minor congener of $\mathbf{1}$, it is reasonable to expect that the production titer and ratio of the two compounds could be favorably improved by mutation and fermentation media manipulations.

In summary, we have described the isolation and structure elucidation of a new thiazolyl peptide that is a highly potent antibiotic. A very efficient isolation procedure was developed to isolate this minor metabolite in the presence of large amounts of structurally-related metabolites.

\section{Experimental}

\section{General Procedure}

All reagents were obtained from Sigma-Aldrich and were used without further purification. The NMR spectra were obtained on a Varian Inova 500 or $600 \mathrm{MHz}$ spectrometers operating at 500 or $600 \mathrm{MHz}$ for ${ }^{1} \mathrm{H}$ and 125 or $150 \mathrm{MHz}$ for ${ }^{13} \mathrm{C}$ nuclei. Residual solvent signal was used as a reference. Optical rotations were obtained on a PerkinElmer 241 Polarimeter, and IR spectral data were obtained on a Perkin-Elmer Spectrum One spectrometer. Highresolution mass spectra were obtained on a Thermo Finnigan LTQ-FT with the standard Ion Max API source (without the sweep cone) and ESI probe.

\section{Producing Organism and Phylogenetic Analysis}

The producing organism was obtained from the American 
Type Culture Collection, Maryland, with accession number 202099. It has been deposited in the Merck culture collection with accession number MA7332. DNA isolation and 16S rDNA sequencing were performed as described previously [25]. Sequence alignments were done using CLUSTAL W [26] and phylogenetic analysis was done in PHYLIP [27] using the neighbor joining algorithm. The analysis was bootstrapped using 200 replicates.

\section{Fermentation Conditions of ATCC 202099 (MA7332)}

A $1.0 \mathrm{ml}$ frozen vegetative stock culture of ATCC 202099 (MA7332) was used to inoculate $50 \mathrm{ml}$ of the seed medium, in a 250 -ml non-baffled Erlenmeyer flask, containing the following components per liter of water: soluble starch (Sigma \#S-9765), $20 \mathrm{~g}$; dextrose, $5.0 \mathrm{~g}$; N-Z amine (Kerry Bio-Science, Hoffman Estates, IL), $3.0 \mathrm{~g}$; Bacto yeast extract (Becton Dickinson), $2.0 \mathrm{~g}$; Pharmamedia (Traders Protein, Memphis, TN), $5.0 \mathrm{~g}$; calcium carbonate, $1.0 \mathrm{~g}$. The culture was incubated at $32^{\circ} \mathrm{C}$ on a rotary shaker operating at $220 \mathrm{rpm}$ for 3 days. Twenty $\mathrm{ml}$ of the resulting culture was used to inoculate $500 \mathrm{ml}$ of seed medium, in a 2-liters non-baffled Erlenmeyer flask, containing the same components as for the $50 \mathrm{ml}$ culture listed above. The culture was incubated at $32^{\circ} \mathrm{C}$ on a rotary shaker operating at $180 \mathrm{rpm}$ for 1 day. The resulting $500 \mathrm{ml}$ culture was used to inoculate 20 liters of media, in a 30 -liters fermenter, containing the following components per liter of water: dextrose, $20 \mathrm{~g}$; soy peptone-type SL (Marcor), 5.0 g; primary dried yeast (PDY) Yeast Products Inc., $10 \mathrm{~g}$; Allophosite (aluminum silicate) (Sigma \#A-3561), $5.0 \mathrm{~g}$; P2000 anti-foam (polymeric material made by Dow Chemical, Midland MI that prevents foaming), $1.0 \mathrm{ml}$. The production fermentation was operated at a temperature of $32^{\circ} \mathrm{C}$, at a back-pressure of $5 \mathrm{psi}$, and an agitation rate of $300 \mathrm{rpm}$. Air was sparged through the fermenter at $10 \mathrm{slpm}$ and $\mathrm{pH}$ was controlled at 7.0 with $10 \% \mathrm{NaOH}$ and $5.0 \%$ $\mathrm{H}_{2} \mathrm{SO}_{4}$. The fermenter was operated for 13 days, at which time the culture was harvested and compounds were extracted.

\section{Fermentation Conditions for Mutant Strains}

The Amycolatopsis fastidiosa strain used in this study was a descendant of ATCC 202099 generated from a classical mutation/strain improvement program which produced increased amounts of $\mathbf{5}$ compared to the wild-type strain. A 2 liters aliquot of frozen inoculum, prepared essentially as outlined by Junker et al. [28], was thawed and transferred to a 280 -liters fermenter containing 180 liters of SNOC seed medium (2.0\% soluble starch Stadex-60 (Staley), $0.3 \%$ NZ Amine-A (Quest Int.), $0.2 \%$ yeast extract \#106 (Springer), $0.5 \%$ cotton seed flour (this is the same as Pharmaedia), $0.3 \% \mathrm{CaCO}_{3}, \quad 0.5 \%$ glucose added post-sterilization, pre-sterilization $\mathrm{pH} 7.0,30$ minutes sterilization at $122 \sim 124^{\circ} \mathrm{C}$ ). The fermentation conditions for the seed fermentation were: temperature, $32^{\circ} \mathrm{C}$; airflow, $100 \mathrm{lpm}$; agitation (Rushton-style impellors), $100 \mathrm{rpm}$; back pressure, $0.7 \mathrm{~kg} / \mathrm{cm}^{2}$.

After 3 4 days of seed fermenter cultivation, 30 liters aliquots of broth were transferred to several 800-liters fermenters containing 600 liters of NOC-AW-2500 production medium (0.4\% Hy-Case SF (Quest Int.), 0.5\% yeast extract \# 106 (Springer), 0.5\% soy peptone (Marcor), $1.0 \%$ glucose added post-sterilization, $3.5 \%$ fructose added post-sterilization, $0.2 \%$ P2000 to control foaming, pre-sterilization $\mathrm{pH} 7.0,45$ minutes sterilization at $122 \sim 124^{\circ} \mathrm{C}$ ). The production fermentation conditions were: temperature, $32^{\circ} \mathrm{C}$; airflow, $150 \mathrm{lpm}$; agitation (axial flow-style impellors), $100 \mathrm{rpm}$; back pressure, $0.7 \mathrm{~kg} / \mathrm{cm}^{2}$. $\mathrm{pH}$ was controlled at $7.0 \pm 0.1$ through the automatic addition of $25 \%$ sulfuric acid or $25 \%$ sodium hydroxide. Dissolved oxygen was controlled at $50 \%$ of saturation through an automatic increase in agitator speed up to $250 \mathrm{rpm}$. Production fermentations were run for $8 \sim 12$ days and approximately $25 \mathrm{~g}$ of $\mathbf{5}$ were produced in 3000 liters of whole broth.

\section{Preliminary Isolation of Thiazomycin}

A 18 liters batch of fermentation broth $(\mathrm{pH} 5.0)$ was extracted twice with 18 and 16 liters each of ethyl acetate by shaking overnight at room temperature and filtered through celite. The ethyl acetate layers were separated from the aqueous phase, pooled and concentrated under reduced pressure to give $7.1 \mathrm{~g}$ of solid. The cell mass with celite was extracted twice with 8 liters of acetone each. Acetone extracts were pooled with ethyl acetate extracts and concentrated to dryness to produce $15.6 \mathrm{~g}$ of solid, which was placed in a sintered funnel and washed with hexane $(4 \times 150 \mathrm{ml})$, suspended in $250 \mathrm{ml}$ of $1: 1$ methylene chloride - methanol and filtered. This extract was adsorbed into $35 \mathrm{~g}$ of Sephadex LH20 and charged on a 2 liters Sephadex LH20 column packed in $1: 4$ hexane - methylene chloride. The column was eluted with two column volumes of $1: 4$ hexane - methylene chloride, followed by a stepwise gradient of varying amounts of methanol in methylene chloride. One $g$ of the solid eluting with hexane - methylene chloride was dissolved in 50\% methanol-methylene chloride and adsorbed on to $5.0 \mathrm{~g}$ of silica gel 60 (230 400 mesh, E-M Scientific, Germany ). It was dried under vacuum and purified using vacuum liquid chromatography on $100 \mathrm{~g}$ of silica gel 60 (230 400 mesh, E-M Scientific, Germany) in sintered funnel ( $20 \mathrm{~cm}$ ID). This was eluted with 0.5 liters of chloroform, followed 
by 1 liter of $10 \%$ methanol-chloroform, 0.5 liters of $20 \%$ methanol-chloroform, 1 liter of $50 \%$ methanolchloroform and finally washed with $5.0 \%$ ammonium hydroxide in $50 \%$ methanol - chloroform. Fraction from the $10 \%$ methanol - chloroform elution was found to contain $\mathbf{5}$. It was concentrated under reduced pressure and lyophilized to yield $650 \mathrm{mg}$ of solid material.

The $650 \mathrm{mg}$ fraction from the silica chromatography was purified by thirteen identical repetitive runs of preparative HPLC using Zorbax SB Phenyl $[(21 \times 250 \mathrm{~mm})$ eluting with a 36 minutes gradient of $40 \sim 50 \%$ acetonitrile water containing $0.1 \%$ TFA]. 5 eluted at $\mathrm{Rt}=32 \sim 33$ minutes. It was lyophilized to yield $42 \mathrm{mg}$ of light yellow powder which was further purified by two preparative HPLC's using a shallower gradient [Zorbax SB Phenyl $(21 \times 250 \mathrm{~mm}$ eluting with a 42 minutes gradient of $40 \sim 50 \%$ acetonitrile-water containing $0.1 \%$ TFA]. 5 eluted in fractions at $\mathrm{Rt}=33 \sim 37$ minutes. The fractions containing $\mathbf{5}$ were pooled and lyophilized to yield $17.5 \mathrm{mg}$ pale yellow powder. Structure and the purity were confirmed by MS, NMR and HPLC analysis. UV (MeOH) $\lambda_{\max }(\log \varepsilon) 222$ (4.77), 288 (4.40), 358 (4.08) nm, IR (ZnSe) $v_{\max } 3389,3096,2929,1669,1638,1535,1476$, 1424 , 1387, 1320, 1253, 1203, 1229, 1099, 1038, $1016 \mathrm{~cm}^{-1},[\alpha]_{\mathrm{D}}^{23}+49.09(c 1.1, \mathrm{MeOH})$, HRESI-MS $(m / z)$ 1435.2707 (calcd for $\mathrm{C}_{61} \mathrm{H}_{58} \mathrm{~N}_{14} \mathrm{O}_{18} \mathrm{~S}_{5}+\mathrm{H}, 1435.2719$ ), 1266.1610 (calcd for $\mathrm{C}_{52} \mathrm{H}_{44} \mathrm{~N}_{13} \mathrm{O}_{16} \mathrm{~S}_{5}, 1266.1633$ ); For ${ }^{1} \mathrm{H}$ and ${ }^{13} \mathrm{C}$-NMR see Table 1 .

\section{One Step Purification of Thiazomycin}

A larger-scale fermentation broth (3000 liters) was extracted with an equal volume of MEK by shaking for 3 hours and concentrated to a mostly aqueous layer. The precipitated thiazolyl peptides were collected by filtration and washed with water and hexane. One gram of the mixture of thiazolyl peptides was dissolved in a $10 \mathrm{ml}$ of a 9: 1 mixture of $\mathrm{CH}_{2} \mathrm{Cl}_{2}-\mathrm{MeOH}$, acidified with $0.3 \mathrm{ml}$ TFA, and adsorbed on to $1.3 \mathrm{~g}$ of silica gel. Solvents were removed under reduced pressure. The dried powder was charged on a dry packed silica gel column $\left(25 \mathrm{~g}, 1 \times 4^{\prime \prime}\right)$ which was pre-equilibrated in $\mathrm{CH}_{2} \mathrm{Cl}_{2}$ and eluted at $17 \mathrm{ml} /$ minute with a step gradient of $\mathrm{MeOH}$ in $\mathrm{CH}_{2} \mathrm{Cl}_{2}$. Elution with $2 \sim 5 \%$ and $5 \sim 7 \% \mathrm{MeOH}-\mathrm{CH}_{2} \mathrm{Cl}_{2}$ separated 3 and 5 respectively. 1 was eluted with $1.0 \% \mathrm{NH}_{4} \mathrm{OH}$ in $10 \%$ $\mathrm{MeOH}-\mathrm{CH}_{2} \mathrm{Cl}_{2}$ (Fig. 3).

\section{Two Step Purification of Thiazomycin (Pilot Plant Scale)}

The fermentation broth was extracted with an equal volume of MEK overnight at room temperature. The aqueous layer was removed and discarded and the organic layer was washed with an equal volume of water. The organic extract was concentrated $5 \times\left(40^{\circ} \mathrm{C}, 30\right.$ torr vacuum $)$. One volume of $n$-heptane was added to the concentrate to precipitate all thiazolyl peptides. The precipitation was tri-phasic. A solid phase settled between the aqueous and organic phases. The organic phase was removed from the batch and discarded. One half volume of THF was added to the aqueous/solid phase. Dissolution of the thiazolyl peptides in the THF led to two layers. The lower aqueous layer was discarded, and the THF layer that contained $\sim 80 \%$ of mixtures of thiazolyl peptides was concentrated to give $800 \mathrm{~g}$ solid containing $23 \mathrm{~g}$ of $\mathbf{5}$. This was purified by two successive silica gel steps as detailed below.

\section{Capture Step}

Silica gel $(3.4 \mathrm{~kg}, 60 \AA ; 37 \sim 63 \mu \mathrm{m})$ was slurried with $1.0 \%$ TFA in tetrahydrofuran, packed into a prep-scale column (7.5 liters bed volume), and was equilibrated with 14 liters of $1.0 \%$ TFA in THF. Crude thiazolyl peptide solids $(800 \mathrm{~g}$, $23 \mathrm{~g} \mathrm{5}$ ) were dissolved in 36.1 liters of tetrahydrofuran and 6 liters of $1: 1.5$ mixture of TFA : THF (cooled to room temperature) were added to the batch. After the feed was acidified, the batch was filtered through a Buchner funnel to remove any solids, and the solution was fed to the column at $500 \mathrm{ml} /$ minute flow rate. On completion of the feed loading, the column was washed with 6.9 column volumes of $1.0 \%$ TFA in THF (52.1 liters). Following the wash, $\mathbf{5}$ was eluted from the column with 7.5 column volumes of $1.0 \% \mathrm{NH}_{4} \mathrm{OH}$ (56.3 liters) in THF. Elution fractions 4 7 were combined to produce the rich cut (15.1 liters; $20.1 \mathrm{~g} \mathrm{5}$; $84 \%$ yield). The ratio of $\mathbf{5}$ and $\mathbf{1} \sim \mathbf{3}$ in the rich cut was 1.5 and 0.014 . The mass balance across the column was $90 \%$. The rich cut was concentrated to solids on a rotary evaporator to yield $52.8 \mathrm{~g}$ of solids (95\% thiazolyl peptide purity).

\section{Polishing Step}

Silica gel (1.4 kg, $60 \AA ; 230 \sim 400$ mesh) was slurried with $1.0 \%$ TFA in THF, packed into a prep-scale column (3.1 liters bed volume), and was equilibrated with 6 liters of $1.0 \%$ TFA in THF. Solids (52.6 g) from the concentrated rich cut were dissolved in $720 \mathrm{ml}$ of $1.0 \%$ TFA in THF. The feed was placed directly on top of the silica and was allowed to adsorb onto the silica gel using gravity. Once the feed was adsorbed onto the silica gel bed, the column was washed with 4 column volumes of $1.0 \%$ TFA in THF (12 liters). 5 was then eluted with 9.5 column volumes (30.2 liters) of $0.125 \% \mathrm{NH}_{4} \mathrm{OH}$. Fractions $4 \sim 10$ were pooled as the thiazomycin rich-cut (13.3 liters) and concentrated under reduced pressure to produce $18.2 \mathrm{~g}$ of $\mathbf{5}$ ( $90 \%$ yield) which was completely free of $\mathbf{1}$ and $\mathbf{3}$ impurities. The purity 
of 5 was over $90 \%$ and the only impurity was THF stabilizer which was removed by triturating with heptane and acetone.

\section{Conversion of Thiazomycin to Nocathiacin I}

To a solution of thiazomycin $(3.0 \mathrm{mg})$ in $\mathrm{MeOH}(0.2 \mathrm{ml})$ at room temperature was added $5 \mu \mathrm{l}$ of concentrated $\mathrm{HCl}$, followed by $\mathrm{NaCNBH}_{3}(1.0 \mathrm{mg})$. The reaction mixture was stirred at room temperature for 1 hour. Purification by similar RP HPLC methods as described earlier gave the desired product $(2.0 \mathrm{mg})$, identical in all aspects (co-HPLC, ${ }^{1} \mathrm{H}$ - and $\left.{ }^{13} \mathrm{C}-\mathrm{NMR}\right)$ with the natural $\mathbf{1}$.

\section{References}

1. Walsh CT. Antibiotics: Actions, Origin, Resistance, ASM Press, Washington, DC (2003)

2. Singh SB, Barrett JF. Empirical antibacterial drug discovery-foundation in natural products. Biochem Pharmacol 71: 1006-1015 (2006)

3. Singh SB, Jayasuriya H, Ondeyka JG, Herath KB, Zhang C, Zink DL, Tsou NN, Ball RG, Basilio A, Genilloud O, Diez MT, Vicente F, Pelaez F, Young K, Wang J. Isolation, structure, and absolute stereochemistry of platensimycin, a broad spectrum antibiotic discovered using an antisense differential sensitivity strategy. J Am Chem Soc 128: 11916-11920 and 15547 (2006)

4 Wang J, Soisson SM, Young K, Shoop W, Kodali S, Galgoci A, Painter R, Parthasarathy G, Tang YS, Cummings R, Ha S, Dorso K, Motyl M, Jayasuriya H, Ondeyka J, Herath K, Zhang C, Hernandez L, Allocco J, Basilio A, Tormo JR, Genilloud O, Vicente F, Pelaez F, Colwell L, Lee SH, Michael B, Felcetto T, Gill C, Silver LL, Hermes JD, Bartizal K, Barrett J, Schmatz D, Becker JW, Cully D, Singh SB. Platensimycin is a selective FabF inhibitor with potent antibiotic properties. Nature 441: 358-361 (2006)

5. Wang J, Kodali S, Lee SH, Galgoci A, Painter R, Dorso K, Racine F, Motyl M, Hernandez L, Tinney E, Colletti S, Herath K, Cummings R, Salazar O, Gonzalez I, Basilio A, Vicente F, Genilloud O, Pelaez F, Jayasuriya H, Young K, Cully D, Singh SB. Platencin is a dual fabf and fabh inhibitor with potent in vivo antibiotic properties. Proc Natl Acad Sci USA 104: 7612-7616 (2007)

6. Jayasuriya H, Herath KB, Zhang C, Zink DL, Basilio A, Genilloud O, Diez MT, Vicente F, Gonzalez I, Salazar O, Pelaez F, Cummings R, Ha S, Wang J, Singh SB. Isolation and structure of platencin: A novel FabH and FabF dual inhibitor with potent broad spectrum antibiotic activity produced by Streptomyces platensis MA7339. Angew Chem Int Ed Engl 46: 4684-4688 (2007)

7. Bagley MC, Dale JW, Merritt EA, Xiong X. Thiopeptide antibiotics. Chem Rev 105: 685-714 (2005)

8. Hensens OD, Albers-Schonberg G. ${ }^{13} \mathrm{C}$ NMR study of thiostrepton and thiopeptin components. J Antibiot 36: 832-845 (1983)

9. Hensens OD, Albers-Schonberg G, Anderson BF. The solution conformation of the peptide antibiotic thiostrepton: a ${ }^{1}$ H NMR study. J Antibiot 36: 799-813 (1983)

10. Northcote PT, Siegel M, Borders DB, Lee MD. Glycothiohexide alpha, a novel antibiotic produced by "Sebekia" sp., LL-14E605. III. Structural elucidation. J Antibiot 47: 901-908 (1994)

11. Northcote PT, Williams D, Manning JK, Borders DB, Maiese WM, Lee MD. Glycothiohexide alpha, a novel antibiotic produced by "Sebekia" sp., LL-14E605. II. Isolation and physical-chemical characterization. J Antibiot 47: 894-900 (1994)

12. Sasaki T, Otani T, Matsumoto H, Unemi N, Hamada M, Takeuchi T, Hori M. MJ347-81F4 A and B, novel antibiotics from Amycolatopsis sp.: Taxonomic characteristics, fermentation, and antimicrobial activity. J Antibiot 51: 715-721 (1998)

13. Li W, Leet JE, Ax HA, Gustavson DR, Brown DM, Turner L, Brown K, Clark J, Yang H, Fung-Tomc J, Lam KS. Nocathiacins, new thiazolyl peptide antibiotics from Nocardia sp. I. Taxonomy, fermentation and biological activities. J Antibiot 56: 226-231 (2003)

14. Constantine KL, Mueller L, Huang S, Abid S, Lam KS, Li W, Leet JE. Conformation and absolute configuration of nocathiacin I determined by NMR spectroscopy and chiral capillary electrophoresis. J Am Chem Soc 124: 7284-7285 (2002)

15. Connolly TP, Regueiro-Ren A, Leet JE, Springer DM, Goodrich J, Huang XS, Pucci MJ, Clark JM, Bronson JJ, Ueda Y. Chemical conversion of nocathiacin I to nocathiacin II and a lactone analogue of glycothiohexide alpha. J Nat Prod 68: 550-553 (2005)

16. Hrnciar P, Ueda Y, Huang S, Leet JE, Bronson JJ. Synthesis of novel nocathiacin-class antibiotics. Condensation of glycolaldehyde with primary amides and tandem reductive amination of amadori-rearranged 2-oxoethyl intermediates. J Org Chem 67: 8789-8793 (2002)

17. Naidu BN, Sorenson ME, Zhang Y, Kim OK, Matiskella JD, Wichtowski JA, Connolly TP, Li W, Lam KS, Bronson JJ, Pucci MJ, Clark JM, Ueda Y. Nocathiacin I analogues: synthesis, in vitro and in vivo biological activity of novel semi-synthetic thiazolyl peptide antibiotics. Bioorg Med Chem Lett 14: 5573-5577 (2004)

18. Naidu BN, Sorenson ME, Hudyma T, Zheng X, Zhang Y, Bronson JJ, Pucci MJ, Clark JM, Ueda Y. Synthesis and antibacterial activity of $O$-substituted nocathiacin I derivatives. Bioorg Med Chem Lett 14: 3743-3746 (2004)

19. Naidu BN, Sorenson ME, Bronson JJ, Pucci MJ, Clark JM, Ueda Y. Synthesis, in vitro, and in vivo antibacterial activity of nocathiacin I thiol-Michael adducts. Bioorg Med Chem Lett 15: 2069-2072 (2005)

20. Naidu BN, Sorenson ME, Matiskella JD, Li W, Sausker JB, Zhang Y, Connolly TP, Lam KS, Bronson JJ, Pucci MJ, 
Yang H, Ueda Y. Synthesis and antibacterial activity of nocathiacin I analogues. Bioorg Med Chem Lett 16: 3545-3549 (2006)

21. Pucci MJ, Bronson JJ, Barrett JF, DenBleyker KL, Discotto LF, Fung-Tomc JC, Ueda Y. Antimicrobial evaluation of nocathiacins, a thiazole peptide class of antibiotics. Antimicrob Agents Chemother 48: 3697-3701 (2004)

22. Regueiro-Ren A, Ueda Y. Mild method for cleavage of dehydroalanine units: highly efficient conversion of nocathiacin I to nocathiacin IV. J Org Chem 67: 8699-8702 (2002)

23. Regueiro-Ren A, Naidu BN, Zheng X, Hudyma TW, Connolly TP, Matiskella JD, Zhang Y, Kim OK, Sorenson ME, Pucci M, Clark J, Bronson JJ, Ueda Y. Novel semisynthetic nocathiacin antibiotics: synthesis and antibacterial activity of bis- and mono- $O$-alkylated derivatives. Bioorg Med Chem Lett 14: 171-175 (2004)

24. Singh SB, Occi J, Jayasuriya H, Herath K, Motyl M, Dorso K, Gill C, Hickey E, Overbye K, Barrett JF, Masurekar P. Antibacterial evaluations of thiazomycin-A potent thiazolyl peptide antibiotic from a Amycolatopsis fastidiosa. J Antibiot 60: 565-571 (2007)

25. Salazar O, Valverde A, Genilloud O. Real-time PCR for the detection and quantification of geodermatophilaceae from stone samples and identification of new members of the genus Blastococcus. Appl Environ Microbiol 72: 346-352 (2006)

26. Thompson JD, Higgins DG, Gibson TJ. CLUSTAL W: improving the sensitivity of progressive multiple sequence alignment through sequence weighting, position-specific gap penalties and weight matrix choice. Nucl Acids Res 22: 4673-4680 (1994)

27. Felsenstein J. Evolutionary trees from DNA sequences: a maximum likelihood approach. J Mol Evol 17: 368-376 (1981)

28. Junker B, Seeley A, Lester M, Kovatch M, Schmitt J, Borysewicz S, Lynch J, Zhang J, Greasham R. Use of frozen bagged seed inoculum for secondary metabolite and bioconversion processes at the pilot scale. Biotechnol Bioeng 79: 628-640 (2002) 